\title{
MANUFACTURING PLANNING AND CONTROL SYSTEM USING TOMOGRAPHIC SENSORS
}

\begin{abstract}
Konrad Niderla ${ }^{1}$, Tomasz Rymarczyk ${ }^{1,2}$, Jan Sikora $^{1}$
${ }^{1}$ Research and Development Center, Netrix S.A., Lublin, ${ }^{2}$ University of Economics and Innovation in Lublin

Abstract. The article presents an idea of a production process control system. Advanced automation and control of production processes play a key role in maintaining competitiveness. The proposed solution consists of sensor networks for measurement process parameters, production resources and equipment state. The system uses wired and wireless communication, which gives possibility to acquisition data from existing in enterprise sensors and systems as well as acquisition data from new systems and sensors used to measure all processes, starting from production preparation to the final product. The solution contains process tomography sensors based on electrical capacitance tomography, electrical impedance tomography and ultrasound tomography. The use of tomographic methods enables to manage the intelligent structure of the companies in terms of processes and products. Industrial tomography enables observation of physical and chemical phenomena without the need to penetrate inside. It will enable the optimization and autooptimization of design processes and production. Such solutions can operate autonomously, monitor and control measurements. All sensors return to the system continuous data about state of processes in some technologically closed objects like fermenters. Process tomography can also be used to acquisition data about a flow of liquids and loose ingredients in pipeline based on transport systems. Data acquired from sen sors are collected in data warehouses in order to future processing and building the knowledge base. The results of the data analysis are showed in user control panels and are used directly in the control of the production process to increase the efficiency and quality of the products. Control methods cover issues related to the processing of data obtained from various sensors located at nodes. Monitoring takes place within the scope of acquired and processed data and parameter automation.
\end{abstract}

Keywords: process tomography, manufacturing execution system, production control system

\section{SYSTEM PLANOWANIA I KONTROLI PRODUKCJI Z WYKORZYSTANIEM CZUJNIKÓW TOMOGRAFICZNYCH}

\begin{abstract}
Streszczenie. $W$ artykule przedstawiono idę systemu kontroli procesu produkcyjnego. Zaawansowana automatyzacja i kontrola procesów produkcyjnych odgrywaja kluczowa rolę $w$ utrzymaniu konkurencyjności. Proponowane rozwiązanie składa się z sieci czujników do pomiaru parametrów procesu, zasobów produkcyjnych i stanu wyposażenia. System wykorzystuje komunikację przewodowa i bezprzewodowa, która umożliwia pozyskiwanie danych z istniejących $w$ przedsiębiorstwach czujników i systemów, a także pozyskiwanie danych z nowych systemów i czujników używanych do pomiaru wszystkich procesów, poczawszy od przygotowania produkcji do produktu końcowego. Rozwiazanie zawiera czujniki tomografii procesowej oparte na elektrycznej tomografii pojemnościowej, elektrycznej tomografii impedancyjnej $i$ tomografii ultradźwiękowej. Zastosowanie metod tomograficznych umożliwia zarządzanie inteligentna struktura firm pod względem procesów i produktów. Tomografia przemystowa umożliwia obserwację zjawisk fizycznych $i$ chemicznych bez potrzeby penetracji wewnatrz. Umożliwi to optymalizację $i$ automatyczna procesów projektowych i produkcji. Takie rozwiąania moga działać autonomicznie, monitorować i kontrolować pomiary. Wszystkie czujniki przekazuja do systemu ciagłe dane o stanie procesów w niektórych technologicznie zamkniętych obiektach, takich jak fermentory. Tomografia procesowa może być również wykorzystywana do pozyskiwania danych o przeplywie płynów i luźnych składników w rurociagu w oparciu o systemy transportowe. Dane uzyskane z czujników gromadzone są w hurtowniach danych $w$ celu ich dalszego przetwarzania $i$ budowania bazy wiedzy. Wyniki analizy danych sa wyświetlane $w$ panelach sterowania użtkownika $i$ sa wykorzystywane bezpośrednio $w$ kontroli procesu produkcyjnego w celu zwiększenia wydajności i jakości produktów. Metody kontroli obejmuja zagadnienia związane z przetwarzaniem danych uzyskanych z róznych czujników zlokalizowanych $w$ węzłach. Monitorowanie odbywa się w ramach pozyskanej i przetwarzanej automatyzacji danych i parametrów.
\end{abstract}

Słowa kluczowe: tomografia procesowa, system realizacji produkcji, system kontroli produkcji

\section{Introduction}

First Information Technology systems in the world were used in enterprises in 1960's when early computers appeared. Firstly, systems cover small parts of operating space, like ROP systems (Reorder Point), which were charge of replenishment of stock when inventory drops down to zero. Later, systems grow up, MRP (Material requirement planning) was built with cooperation between J.I. Case - manufacturer of tractors and IBM. Those kinds of systems were charge of planning material demand in production process. Next step, MPC systems (Manufacturing planning and control) were built. Those systems gave the possibility of collecting data in storages. Of course, from our point of view every system was very primitive, technological limitations like small amount of memory, mass storage problems - we didn't know hard drives, we knew magnetic tapes, lack of processors - which were slow, had limitations, for example first processors couldn't calculate square root. Systems were very expensive and big, difficult to use, they needed a lot of stuff who had mastered a technique [10]. In 70's systems and IT companies were developing. In 1972 five IBM's workers founded SAP company, and one year later completes its first accounting system [24]. In August 1977 was founded Oracle, in 1979 they started selling first relational database systems (in fact it was version number two) [4]. In 80's works were conducted on second generation of systems, like MRP-II (Manufacturing resource planning). MRP-II included stock reporting as well as production and procurement scheduling and cost reporting. New abbreviation CIM (computer integrated manufacturing) was introduced in the middle of 80 's. The CIM model introduced a concept of integration all kinds of electronic data processing application in all enterprise's divisions connected with production, starting from design department to quality control, although implementation often failed due to complexity, lack of standardization and technologies [17]. Next type of IT systems is called ERP (Enterprise resource planning). The term was used by the Gartner Group in 1990 first time. ERP systems attempts to integrated processes and data in organization. The data are stored in a single database. The database stores, shares and manages data from different departments [6]. In practice the name ERP is more ambition than system really is, because usually they are administrative, automation accountant tasks and material management systems. Gap between ERP and lower level systems like MRP-II in CIM model was filled by MES systems (Manufacturing execution system). First time term MES was promulgate in 1992 by AMR Research Inc. The MES systems are based on functionality for planning, execution and control production process, as well as act MES must react in real time in case of interrupt. MES systems were overtaken by ERP, because ERP systems are helping business executive with financial decisions. The plant level executives, who had to take important decisions, can't rely on business information. Crucial data comes from the plant, and plays significant role in process optimization, thus MES systems are becoming important software in manufacturing ecosystems [28]. 
To meets modern challenges production control systems should satisfy the following requirements [8]:

- enterprise integration: cooperating enterprises should integrate related management systems to effectively and efficiently exchange information,

- distributed organization: enterprises should integrate knowledge transfer between parts of company as well as between cooperating companies,

- heterogeneous environment: cooperating companies usually have different organizational and information systems; new age environment should integrate them,

- interoperability: different systems means different platforms, programming languages, data format, models,

- open and dynamic structure: integration new or removing existing subsystem should be prepared rapidly, without disturbances for working environment,

- cooperation: enterprise should cooperate with suppliers and customers for materials, supplies, parts fabrication, product commercialization etc.,

- integration of humans with software and hardware: computers must be integrated with humans on the whole product life cycle,

- Agility: agile means ability to rapidly adapting to new situation. In manufacturing environment this new situation can be connected with customers' requirements or e.g. new equipment features,

- Scalability: operational space and resources should be able to expand without breaking of existing organizational connections,

- fault tolerant: The system has to be fault tolerant on all working levels. It should minimize bad impact of failures, detect it and recover system.

In recent years technology has evolved. We have available new equipment and software. Almost everyone has a smartphone in their pocket, a computer and a tablet on their desk. We can use cheap sensors and hardware, RFID, Beacons, Internet of Things are very fashionable words. We have access to Cloud Computing technology which offer on demand almost unlimited computing power and storage space, but also, we can use cognitive services which can be helpful to process huge amount of data. The whole electronic world is more accessible, it gives new possibilities in building MES systems. We can collect data from large number of various sensors, Cloud computing and Big Data allows us to store and process collected data. Increase technology also has a big impact on the development of process tomography. We can build smaller, cheaper and more useful device as well as smarter, faster and more accurate algorithms. At the same time, customers' requirements are constantly growing. They needs customized products, shorter production time, possibility to making changes, higher quality and lower price. World continuously changing, then we have to build systems significantly more elastic and more responsive for customers' needs. The above expectations and possibilities can meet in a common point.

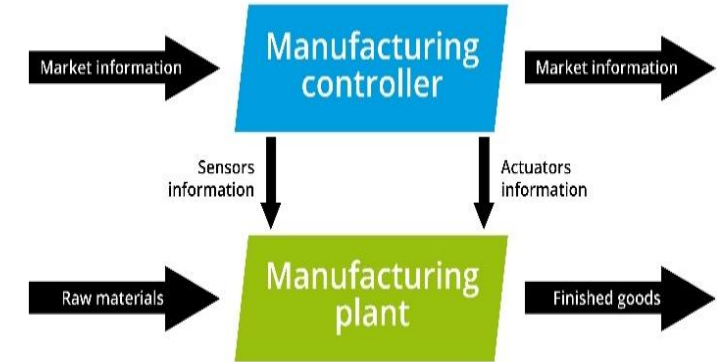

In this paper we propose production control system that will meet users' and management's needs, will be able to collect the right data, process it using the latest solutions, and return the results to both processes and users. The distributed and open architecture of the solution should allow use of a wide range of sensors and measuring and executive devices, including process tomography systems. The solution should also enable dynamic adaptation to changing conditions and needs e.g. the need to add new sensors.

\section{System background}

According to Baker, factory control is charge of conduct production process to make desired product from manufacturing resources and information. Manufacturing control model was presented on [1]. Baker wrote that system should decide what to produce, how much to produce, when production is to be finished, what resources to use, how and when use them and make them available, when to release jobs into the factory, which job to release, job routing, and operation sequencing [1]. Single central factory controller has difficulty to deal with complexity coming from production system (e.g. complexity of data management, uncertainty connected with demand and resources availability, lags between events and relevant information processing, real-time constraints). Popular solution for these kinds of problems is separation of responsibilities into several decisional entities, introducing a non-centralized control system. In our case non-centralized means division of a global control process based on a selected splitting criterion e.g. functional [27]. Functional horizontal division was defined by Association of German Engineers, that works on MES Systems in details. In their guideline VDI 5600 they define 3-levels manufacturing company structure. As can be seen from, business management is represented by ERP systems, production management is represented by MES system, and finally production level is represented by workplaces, machines and equipment. Manufacturing execution systems are subject of work for a lot of organizations. They are trying to specify standards which can help implement system in manufacturing enterprises. To define common functionality, MES functions specified by different standards was presented in Table 1 [25]. There was selected four standards: Manufacturing Execution Solution Association MESA [16], Normenarbeitsgemeinschaft für $\mathrm{Me} \beta$ und Regeltechnik in der chemischen Industrie NAMUR [18], VDI-Kompetenzfeld Informationstechnik [11], National Institute of Standards NIST [2].

As you can see on the Table 1, all considered standards have defined areas connected with detailed planning, quality management, master data management. Other functionality is described in three or less number of specification. This may indicate that these functions are specific to selected industries. The MES system occupies a central position in a manufacturing company. According to VDI, MES is charge of nine areas: detailed planning and control, information management, quality management, human resources management, production facility management, performance analysis, data collection and material management. MES is capable of exchanging information between the business level and the production level. The production level includes complex machines and subsystems for production tasks, which are involved in production process. Production equipment generate data which MES system uses to represent the actual state. From this point of view, production control system should integrate equipment, machines and exchange data in way which enable control over production subsystems [11]. 
Table 1. MES Functions

\begin{tabular}{|l|cc|c|c|}
\hline & \multicolumn{1}{|c|}{ MESA NAMUR } & VDI & NIST \\
\hline L abour Mana gement & $\mathrm{X}$ & $\mathrm{X}$ & \\
\hline Requirements Planning & \multicolumn{1}{|c|}{$\mathrm{X}$} & & \\
\hline Gross P1anning & \multicolumn{1}{|c|}{$\mathrm{X}$} & & \\
\hline Detailed Planning & $\mathrm{X}$ & $\mathrm{X}$ & $\mathrm{X}$ & $\mathrm{X}$ \\
\hline Quality Management & $\mathrm{X}$ & $\mathrm{X}$ & $\mathrm{X}$ \\
\hline $\begin{array}{l}\text { Prod. Inventory } \\
\text { Managem ent }\end{array}$ & $\mathrm{X}$ & $\mathrm{X}$ & $\mathrm{X}$ \\
\hline Resource Management & $\mathrm{X}$ & $\mathrm{X}$ & $\mathrm{X}$ \\
\hline $\begin{array}{l}\text { Equipm ent } \\
\text { Managem ent }\end{array}$ & $\mathrm{X}$ & $\mathrm{X}$ & $\mathrm{X}$ \\
\hline Manufacturing Control & $\mathrm{X}$ & $\mathrm{X}$ & & \\
\hline Traceability/G enealogy & $\mathrm{X}$ & & $\mathrm{X}$ \\
\hline Production Reporting & $\mathrm{X}$ & $\mathrm{X}$ & $\mathrm{X}$ \\
\hline Machine Control & $\mathrm{X}$ & & \\
\hline $\begin{array}{l}\text { Production Data } \\
\text { Acquisition }\end{array}$ & $\mathrm{X}$ & $\mathrm{X}$ & $\mathrm{X}$ \\
\hline $\begin{array}{l}\text { Master Data } \\
\text { Managem ent }\end{array}$ & $\mathrm{X}$ & $\mathrm{X}$ & $\mathrm{X}$ \\
\hline
\end{tabular}

\section{LEVELS}

\section{SYSTEMS}

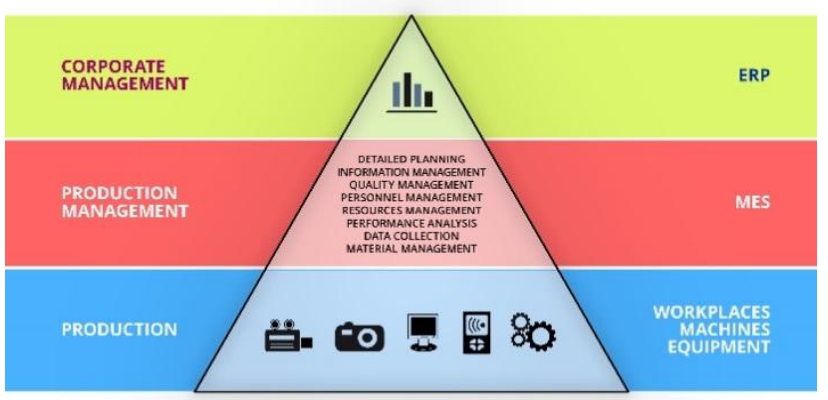

Fig. 2 VDI-5600 Manufacturing company levels model

\section{LEVELS}

SYSTEMS

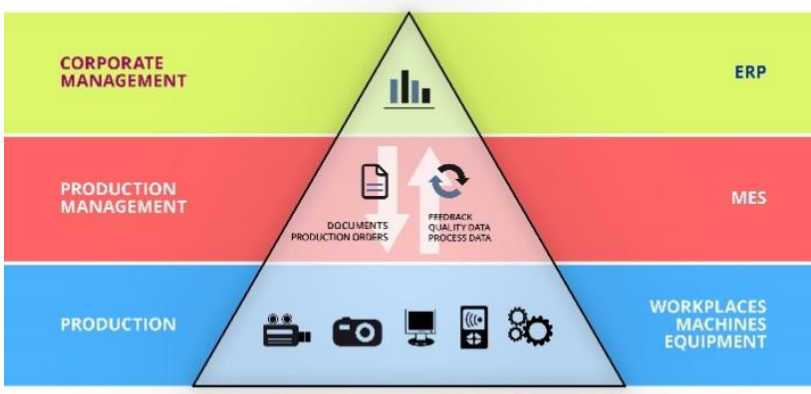

Fig. 3. Vertical system communication

\section{LEVELS}

SYSTEMS

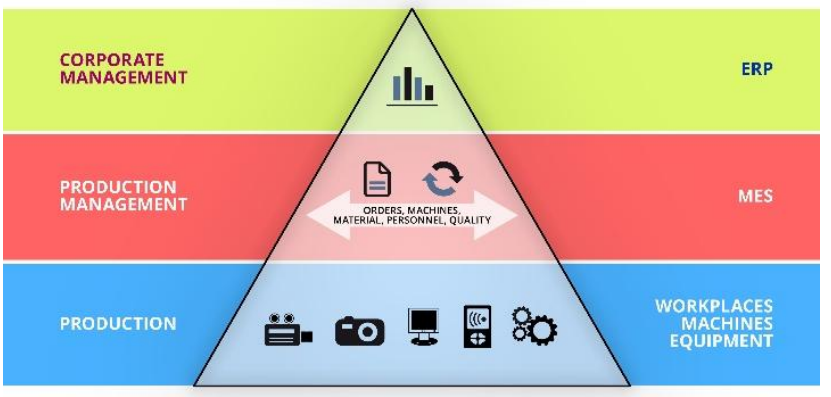

Fig. 4. Horizontal system communication

\section{Distributed system}

Manufacturing companies often have very complex and complicated operational processes, additionally it happens that operations are extended over many partnership companies which make smaller parts of products or plays role in a part of production processes. To stay on the market firms should change dynamically products, and have always fast reaction to disturbances. This need forces the use of systems with high level interactions and integration, at the same time with great flexibility for changes in configuration or components. This requirement meets distributed systems sometime called collaborative automated production systems. These systems have several special features [13]:

- A complex problem is divided into several small problems, using a distributed approach, with the development of intelligent building blocks, i.e. control units.

- Each control unit is autonomous, having its own objectives, knowledge and skills, and encapsulating intelligent functions, however, none of them has a global view of the system.

- The global decisions (e.g. the scheduling, monitoring and diagnosis) are determinate by more than one control unit, i.e. the control units need to work together, interacting in a collaborative way to reach a production decision.

- Some control units are connected to physical automation devices, such as sensors, robots and CNC machines.

We have a number of tools to implement this kind of systems. Agents, holons, webservices and microservices can be used. As communication protocols very popular are JSON (JavaScript Object Notation) [5] and XML (eXtensible Markup Language) [29], and for aggregate events MQTT (MQ Telemetry Transport) [9] protocol can be used. Agents are autonomous, intelligent, adaptive and cooperative objects, the most suitable definition for agents is: "An autonomous component that represents physical or logical objects in the system, capable to act in order to achieve its goals, and being able to interact with other agents, when it does not possess knowledge and skills to reach alone its objectives" [14]. The word "holon" was proposed by Koestler in 1971. This is combination of Greek words "holos" and "on". Greek word "holos" meaning whole and the Greek suffix "on" meaning particle od part like proton or neutron. Holon can function as part another object and at the same time it is autonomous whole [8]. Holonic manufacturing system idea was proposed in 1990. HMS contains autonomous building blocks called holons, They have ability to transforming, transporting, storing and validation information or physical objects. Holons cooperate each other during the process, in order to achieve production goals. The holon in HMS must enable features [7]:

- autonomy: Each holon must be able to create, control and monitor the execution of its own plans and/or strategies, and to take suitable corrective actions against its own malfunctions,

- cooperation: Holons must be able to negotiate and execute mutually acceptable plans and take mutual actions against malfunctions,

- openness: The system must be able to accommodate the incorporation of new holons, the removal of existing holons, or modification of the functional capabilities of existing holons, with minimal human intervention, where holons or their functions may be supplied by a variety of diverse sources.

Web service is data source or application accessible via HTTP (HypeText Transfer Protocol) or its encrypted version HTTPS (HyperText Transport Protocol Secure) protocols. Opposite to WebApplication webservices are designed to communicate with other programs, not users. The most popular webservice protocol is SOAP (Simple Object Access 
Protocol) - add a header to XML message before it is transferred over HTTP [3].

Microservice is module which supports a specific business goal, and uses well defined interface to communicate with other sets of services. Microservices architecture is an approach to developing a single application as a set of small services, each running in its own process and communicating with lightweight protocol [21].

\section{System idea}

Whole system idea was presented on Fig. 5. According to VDI 5600 guideline, system is divided horizontally in three main operational levels. The first level contains business systems, working in manufacturing company, it includes customer web portal, external information systems like ERP, web and mobile platform. First level already contains internal information systems like mobile production supervising application and other systems used in the enterprise. Business applications communicate with second level application via data services like WebApi, WebServices, WCF services, with use any communication formats and protocols like JSON, XML MQTT etc.

Data services should be projected as façade for master data service, this will allow to add any chosen communication method. Second level a larger number of elements. The start components of the system are Goals agent. The primary functions of Goals agent are asking data store about commissions queue, checking resources availability, knowledge about products and finally send commissions to Automation and customization product service. Goals agent ask Expert system service about expert's knowledge about product's production process. Expert system collects expert knowledge, questions and answers about production process. This data will be used in future to optimization production process. Goals agent also takes data from supplier's databases, HR system, warehouse system and data about production needs. Automation and customization product service prepare production process, divide commissions to smaller atomic parts and send to Plant floor objects. Plant flor objects we can define as services connected with physical factory equipment like sensors, actuators, PLC, CNC machines as well as data readers from transport equipment, measurement systems, RFID gates etc. As a plant floor object could be installed process tomography equipment to measure process parameters in closed production objects like pipelines or chemical reactors. Automation and customization module consists products reference models and adaptive control subsystem. The task of the automation module is to control the manufacturing process and receive process data. Collected data are used to adjust the control system settings. Intelligent measurement module is used to extend the measuring system with additional sensors and devices. This is area where process tomography equipment will be used. Additionally, could be used sensors which are important from production management and business management point of view, but which were not prepared by devices' manufacturers. This module contains measurement subsystem and intelligent sensors controller. Effect agent should collect data about production results, this data is collected in big data service, and after process will be use in future. The analytical engine is based on computational intelligence algorithms. This module takes data, process them, and returns as synthetic information ready to use in future processing. The last described module is communication module. This system's part is charge of data exchanging between production system and external applications like web applications, ERP systems, mobile applications as well as IT systems for control and supervisor production.

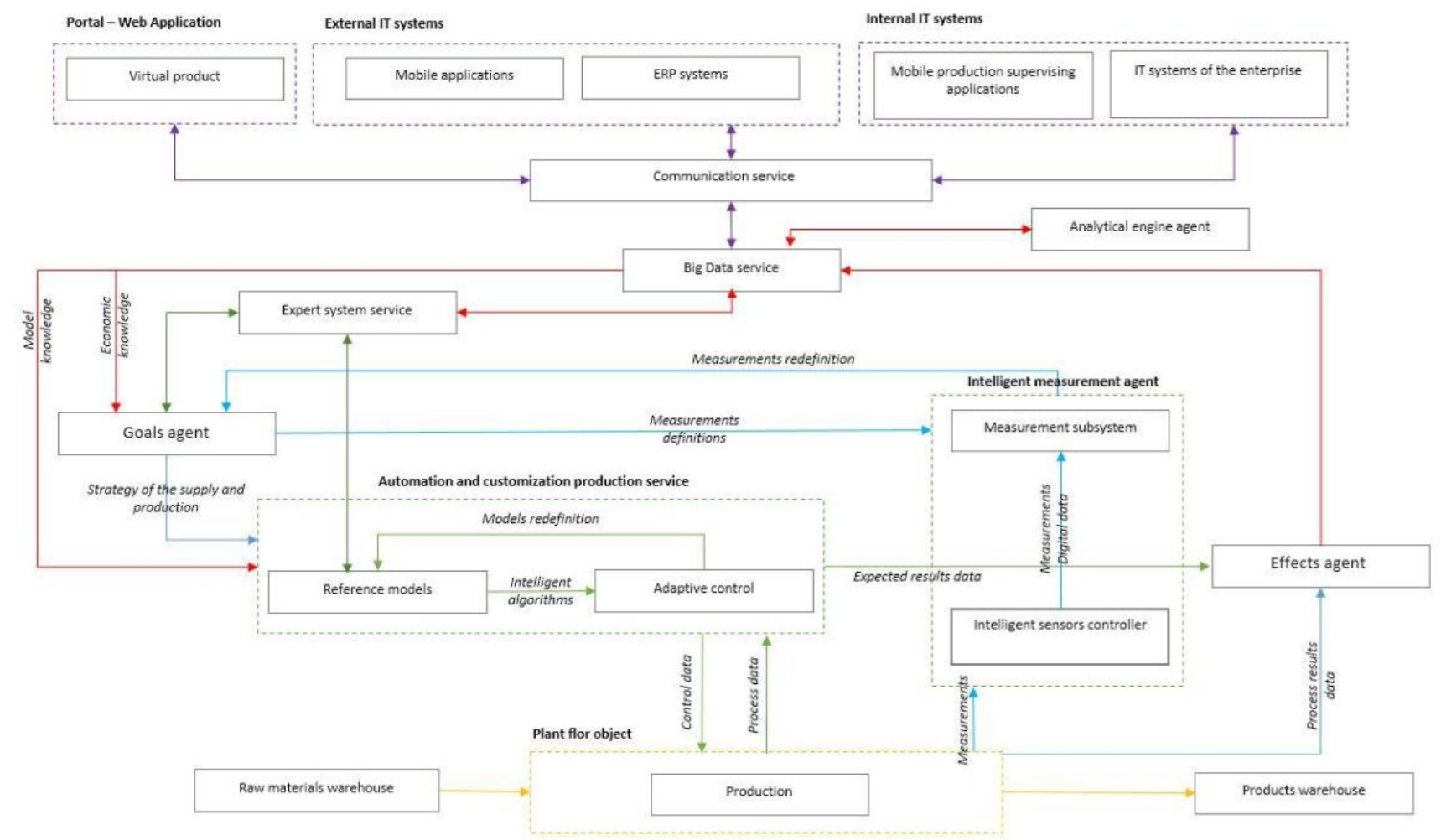




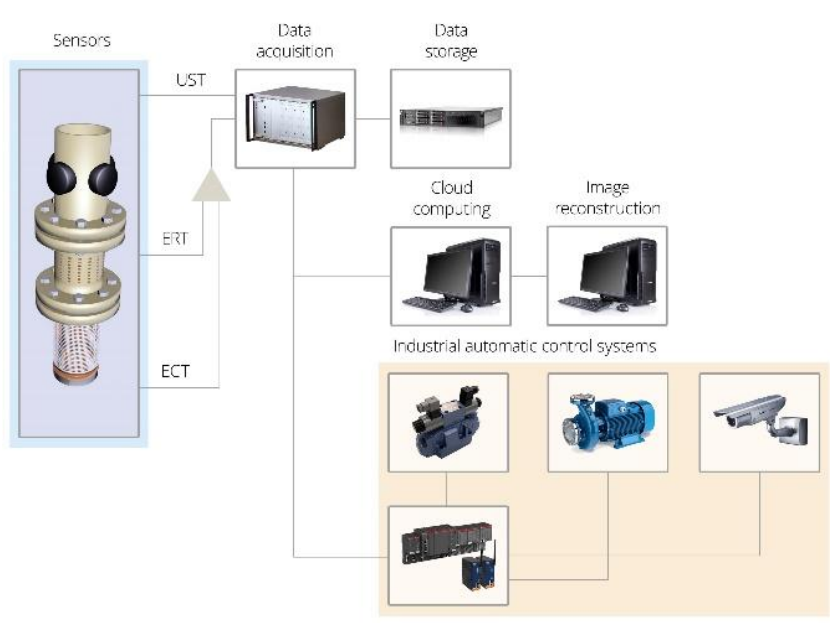

Fig. 6. The data acquisition system

The idea to use tomography to monitoring industrial processes emerged in the nineties. Since then, various tomographic methods have appeared, including: electrical tomography, magnetic, optical, ultrasonic, microwave and radioactive tomography. This concept requires new data processing strategies and a correct extension of the classical control theory, because the latter is not developed enough for a large amount of sensor data and must be created on a non-parametric criterion $[12,15,19,20,22,23,26$, 30]. Industrial tomography applications are usually a challenge for obtaining spatial distribution data from observations beyond the boundary of the process. Sensor networks with the feedback loops are the fundamental elements of the production control. Here, the future belongs to distributed sensors and imaging (Fig. 6).

\section{Examples}

Algorithms manual control and automatic cover issues related to the processing of data obtained from various sensors located at key nodes of the system. Supervision and control is in the range of acquired and processed data and device parameters implementing automation such as servo valves, pumps supply and rotary flow, etc. The primary / main feature of the use of methods of wireless is to obtain important information about the process and the state of the installation in real time by persons having strategic importance in the management and technical supervision. The Solution of the diagram of a multiphase flows system is presented in Fig. 7. Figure 8 shows the example of the image reconstruction by ECT, UT and EIT.

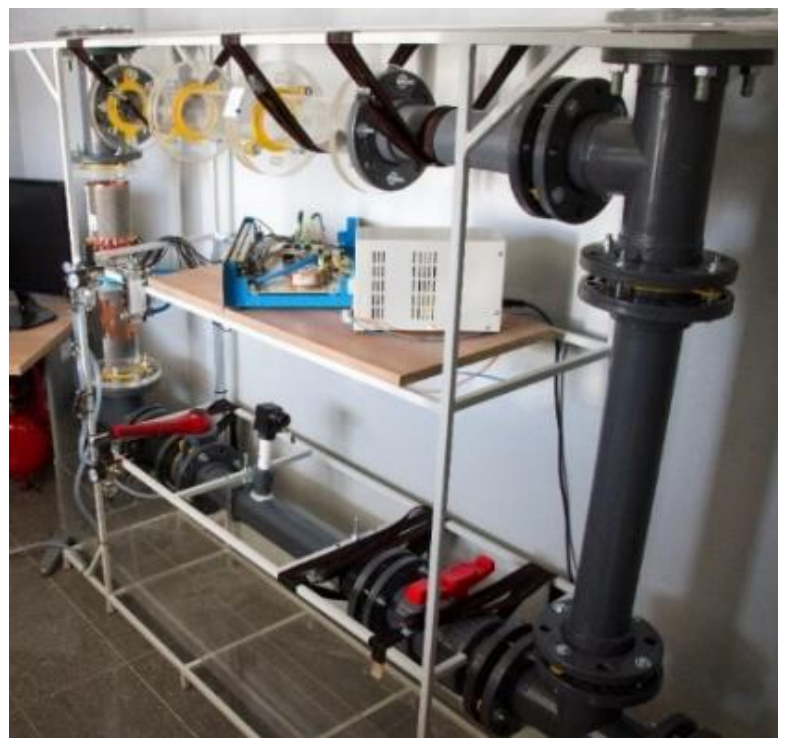

Fig. 7. Tomographic measurement system

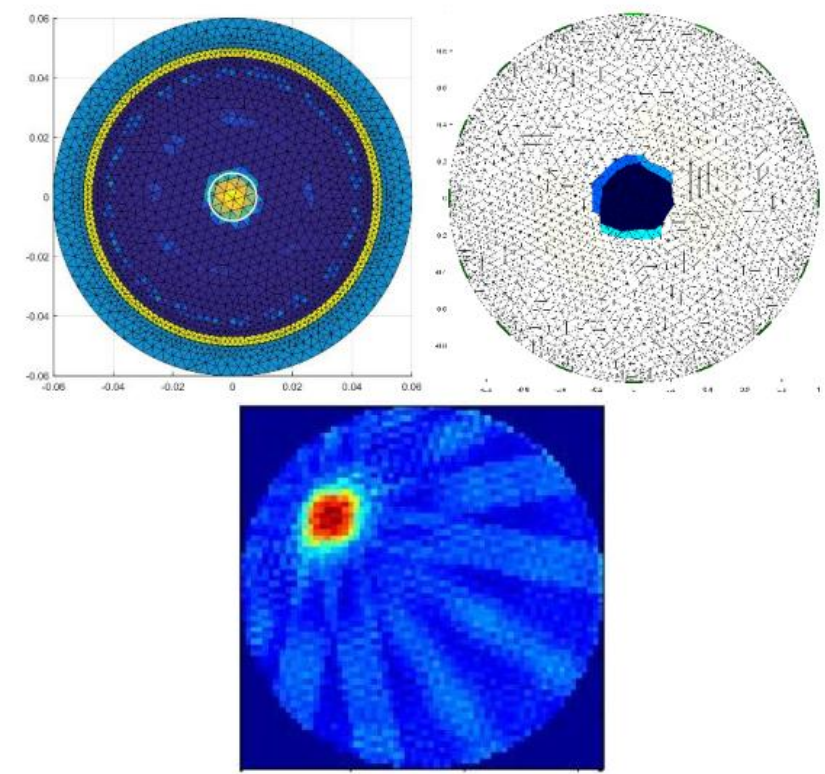

Fig. 8. Example of the image reconstruction by ECT, EIT and UST

\section{Conclusion}

In this work, there was presented the control and steering in cyber-physical system based on an idea of a production process control system and tomographic sensors. They were made virtual arrays equipped with active elements, control algorithms of manual and automatic. Running an application for processing and data obtained from various sensors disposed at key nodes installation. Supervision and control is in the range of acquired and processed data and parameters of devices implementing automation. A new science will define new mathematical foundations with formalisms to specify, analyze, verify and validate systems that monitor and control physical objects and entities. This system includes new measurement techniques and designs innovative smart measuring devices. The application structure covers a communication interface, unique algorithms for optimization and data analysis algorithms for image reconstruction and process monitoring

\section{References}

[1] Baker A.D.: A Survey of Factory Control Algorithms which Can be Implemented in a Multi-Agent Heterarchy: Dispatching, Scheduling, and Pull. Journal of Manufacturing Systems 1998.

[2] Barkmeyer E., Denno P., Feng S., Jones A., Wallace E.: NIST Response to MES Request for Information. National Institute of Standard, Gaithersburg 1999.

[3] Christensson P.: Web Service Definition. https://techterms.com. https://techterms.com/definition/web_service [23.02.2018].

[4] Consulting, Burleson. Oracle history. http://www.dbaoracle.com/t history_oracle.htm [14.02.2018].

[5] ECMA. The JSON Data Interchange Syntax. s.l. : ecma-international.org, 2017.

[6] Elragal A., Haddara M.: The Future of ERP Systems: look backward before moving. Procedia Technology 5/2012

[7] Fletcher M., Garcia-Herreros E., Christensen J.H., Deen S.M., Mittmann R.: An Open Architecture for Holonic Cooperation and Autonomy.

[8] Giret A., Botti V.: Holons and Agents. Journal of intelligent manufacturing $15 / 2004$.

[9] International Business Machines Corporation (IBM), Eurotech. MQTT v3.1 Protocol Specification. s.1. : mqtt.org, 2014.

[10] Jacobs F.R., Weston Jr Ted F.C.: Enterprise resource planning (ERP)-A brief history. Journal of Operations Managem.. 25/2007.

[11] Kletti J., Deisenroth R.: MES Compendium: Perfect MES Solutions based on HYDRA. Springer, 2012

[12] Kłosowski G., Gola A.: Risk-based estimation of manufacturing order costs with artificial intelligence. Proceedings of the 2016 Federated Conference on Computer Science and Information Systems, IEEE, 2016, 729-732.

[13] Leitão P., Colombo A.W.: Petri net based Methodology for the Development of Collaborative Production Systems 1. IEEE, 2006.

[14] Leitao P.: Agent-based distributed manufacturing control: A state-of-the-art survey. Engineering Applications of Artificial Intelligence 22/2009.

[15] Mazurkiewicz D.: Maintenance of belt conveyors using an expert system based on fuzzy logic. Archives of Civil and Mechanical Engineering 15(2)/2015, 412-418. 
[16] MESA. Enterprise-Control System Integration Part 1: Models and Terminology. MESA, 2000.

[17] Meyer H., Fuchs F., Thiel K.: Manufacturing Execution Systems. Optimal Design, Planning, and Deployment. McGraw-Hill, 2009

[18] NAMUR. Functions and Examples of Operations Control Level Solutions. Technical report. Normenarbeitsgemeinschaft für Meß- und Regeltechnik in. 2003

[19] Polakowski K., Filipowicz S., Sikora J., Rymarczyk T.: Tomography Technology Application for Workflows of Gases Monitoring in The Automotive Systems. Przegląd Elektrotechniczny 84(12)/2008, 227-229.

[20] Polakowski K., Filipowicz S.F., Sikora J., Rymarczyk T.: Quality of imaging in multipath tomography. Przeglad Elektrotechniczny 85(12)/2009, 134-136.

[21] Rouse M.: Microservices. http://searchmicroservices. techtarget.com. $\mathrm{http}: / /$ searchmicroservices.techtarget.com/definition/microservices [23.02.2018].

[22] Rymarczyk T., Filipowicz S., Sikora J., Polakowski K.: A piecewise-constant minimal partition problem in the image reconstruction. Przegląd Elektrotechniczny 85(12)/2009, 141-143.

[23] Rymarczyk T., Sikora J., Waleska B.: Coupled Boundary Element Method and Level Set Function for Solving Inverse Problem in EIT. 7th World Congress on Industrial Process Tomography, WCIPT7 2013, 312-319.

[24] SAP https://www.sap.com/corporate/en/company/history.html [14.02.2018].

[25] Schmidt A., Otto B., Österle H.: A Functional Reference Model for Manufacturing Execution Systems in the Automotive Industry. Wirtschaftinformatik Proceedings 89/2011.

[26] Smolik W., Radomski D. Performance evaluation of the iterative image reconstruction algorithm with sensitivity matrix updating based on real measurements for electrical capacitance tomography. Measurement Science and Technology 20(11)/2009, 115502.

[27] Trentesaux D.: Distributed control of production systems. Engineering Applications of Artificial Intelligence 22/2009.

[28] Vitliemov P.: About Manufacturing Execution Systems. Proceedings of the University of Ruse 52(5.1)/2013.

[29] W3C. Extensible Markup Language (XML) 1.0 (Fifth Edition). s.l.: W3C, 2008.

[30] Wajman R., Fiderek P., Fidos H., Jaworski T., Nowakowski J., Sankowski D. Banasiak R.: Metrological evaluation of a 3D electrical capacitance tomography measurement system for two-phase flow fraction determination, Meas. Sci. Technol. 24/2013, 065302 .
M.Sc. Konrad Niderla

e-mail: konrad.niderla@ netrix.com.pl

He manages at Netrix S.A. the programming and research department. In his work he deals with the development of new methods of control and measurement in the field of automation and tomography as well as artificial intelligence.

\section{h. D. Eng. Tomasz Rymarczyk}

e-mail: tomasz@rymarczyk.com

$\mathrm{He}$ is the director in Research and Development Center in Netrix S.A. and the director of the Institute of Computer Science and Innovative Technologies in the University of Economics and Innovation, Lublin, Poland.. He worked in many companies and institutes developing innovative projects and managing teams of employees. His research area focuses on the application of non-invasive imaging techniques, electrical tomography, image reconstruction, numerical modelling, image processing and analysis, process tomography, software engineering, knowledge engineering, artificial intelligence and computer measurement systems.

\section{Prof. Jan Sikora}

e-mail: sik59@wp.pl

He graduated from the Faculty of Electrical Engineering of the Warsaw University of Technology. During his 34 years of professional work, he has earned all grades, titles and positions at his home university, including the position of full professor. He has been associated since 1998 with the Institute of Electrical Engineering in Warsaw. In the years 2001-2004, he worked as a senior research fellow at the University College London in the Group of Optical Tomography. S.R. Arridge. He was employed at the Faculty of Electrical Engineering and Computer Science. Actually, he works in the R\&D Department at Netrix S.A. otrzymano/received: 10.07.2018 przyjęto do druku/accepted: 15.09 .2018
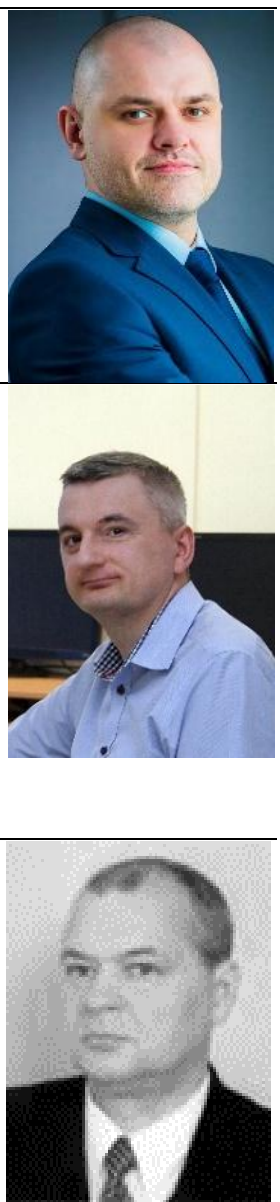